\title{
Exploration of Marx's Philosophy of Law and Its Inspiration to China
}

\author{
$\mathrm{Li} \mathrm{Li}$
}

\section{School of Arts and Law, Wuhan University of Technology, Wuhan ,430070, China}

\section{6@qq.com}

\begin{abstract}
Marx's Philosophy of Law is an important part of Marxist theory. Marx, as one of the founders of Marxism theory, his legal thoughts not only provides a powerful ideological tool for us to understand and change the world, but also guides socialist modernization construction of our country. This article begins from the text analysis, through reading a lot of classic works of Marx , this paper summarized two points of Marx's philosophy of law: 1, law is rooted in material life.2, law is the reflection of the ruling class' will, and through further analysis this paper found out that the reasonable kernel of Marx's philosophy of law is--humanistic spirit. China as the largest socialist country in the world, in the process of governing the country according to law must adhere to Marx's law philosophy, and carry out the modern essence of Marx's law philosophy, always put starting point and foothold of ruling of law on caring about human.
\end{abstract}

Keywords: Marx; Philosophy of Law; Humanism; China; law-construction

\section{Introduction}

Law philosophy is the product of human civilization, and it plays an important role in the development of human history. Marx's law philosophy thought is a revolutionary ideology, inheriting predecessors' theoretical achievements. The development of the idea overthrows the established law philosophy system of idealism set up by the bourgeoisie thinkers and applies world outlook and methodology of historical materialism to the philosophy of law, enabling us to better know and change the world with philosophy of law.

The research of Marx's philosophy of law is still not deep in China, and it even hasn't been given a sufficient attention in the world. Due to the short history of law philosophy studies and many ups and downs and other reasons, there are some problems in the study of philosophy of law, such as severe politicized tendency, insufficiency of depth, systematicness, integrity and practicality in theoretical research, which seriously hinder the progress of our country's legal philosophy research. According to the summary of previous research, I find that people mainly focus on the subjective aspect of the economic base determining the superstructure during the study of Marx's legal philosophy, and relatively ignores to explore legal axiology, another important content of Marx's law philosophy.

The paper bases on the text research of Marx's law philosophy by historical method, class analyzing method, science abstract method and literature study method .through reading lots of Marx's classical literature I intend to reveal the rational core of Marx's law philosophy-- humanistic spirit .

\section{The Connotation of Marx's Philosophy of Law}

\subsection{Law is Rooted in Material Life}

Marx points out that, in Introduction to the Critique of Political Economy, if we want to understand the relationship of law, we cannot solely start from abstract concepts by themselves, or from the general development of law spirits. On the contrary, law is rooted in relations in material life, called "civil society", from which we can dig into[1]. The origin of law and the law system is indeed the social production mode, and the direct origin of them is the social economic foundation. Marx believes that law inevitably comes from real social process, the initial production, distribution, exchange and consumption activities of human must need a common rule to summarize them. In the initial stage they may only be some random behaviors. With the development of society, the behaviors change into the inevitable rules, first characterizing by habit, then after they are accepted by the minority who have the possessions, the habits become law.

Marx applied the viewpoints of historical materialism to investigate the origin of law, then in German ideology, Marx explored law origin from the angle of relations between state and law. Marx and Engels 
pointed out that the development of productive forces caused the refinement of social division of labor and surplus value caused the emergence of private ownership. Meanwhile refinement of social division of labor intensified the conflict between productivity and production relations. In order to harmonize the relationship between internal personal interests and the common interests of private ownership, countries appeared in the form of virtual community, law in the form of the common rules, then as a result, law is in the form of politics in the national level. The origins of law is closely connected with social material connections, rather than with free will or with abstract power.[2]

\subsection{Law is the Reflection of the Ruling Class' Will}

The immortal work Communist Manifesto, 1848, marks formal formation of the scientific system of Marxism, which is not only the declaration of the birth of Marxist theory, but also the declaration of his law philosophy. One of the most outstanding contribution of Marx's philosophy of law is the disclosure of the nature of law , namely, law is the reflex of the ruling class' will increased to the will of the state, and it roots in the material living conditions of the ruling class and is determined by that. [3]Marx critically points out that the so-called capitalist law philosophy is bourgeois interests reflect on the political superstructure, and the law of bourgeois content was determined by the realistic conditions of material life. Marx elaborated this point more detailed in his later writing Kapital.

In Marx's Kapital, here and everywhere, the minority people who have dominant position in the material production will inevitably raise existing established rules to national law and make the law holy, and make useful habits and traditions accumulating in a long time fixed in the form of law. Habits and traditions are the initial unwritten laws; the basis of the status quo is the production relations; the status quo is the order itself; this relationship and order once is accepted by law, it will possess mandatory power, rather than mere chance and simple arbitrary. If a class is in a dominant position, it must dominate the production materials of matter and spirit, and its will can be raised to the national will and its economic ties the law relationship reflecting its will in a seemingly reasonable manner. [4]Because the law reflects the will of the ruling class, bourgeois legal is indeed of hypocrisies.

\section{Humanism - the Core of Marx's Philosophy of Law}

Marx thinks that law as a social ideology, belongs to the category of superstructure, and it must be decided by social existence and restricted by the economic base of an era. The bourgeoisie law is at the service of the bourgeoisie inherently and it is a tool of bourgeois to rule the proletariat. As a result, law is of class nature, however, in the variety of factors influencing law, the primary factor influencing the philosophy law of Marx, of course, is people, not imaginary one, but the real person who engaged in material production labor, rational core of Marx's philosophy of law. This thought can be understood from the following two angles:

The state, society and law are created by man to serve human survival and development. In families and civil society man is of the primacy, the main body, while the state, society and law are decided by families and civil society and by the reality of man who is engaged in the concrete material production. Families and civil society are the real constituents of the state, society and law; they are real spiritual entity exposed by will and existence way of nation .Political countries cannot exist without natural foundation of families and the man-made foundation of civil society. They are necessary conditions for countries to exist. At the same time, in Marx's opinion, the legislative power should not be in the hands of a minority of bureaucratic class, but in a large quantity of class of universal representation.

During the formation and development period of Marx's legal philosophy, Marx attaches great importance to human rights, whose ideas of this kind are based on critical inherits of predecessors' thought, and he points out that human rights possess such characteristics as the nature of historical, social, concrete, relative and conditionality and expansibility of materials. And ultimate development prospect of human rights is everyone can be entitled to human rights; with great development of productivity and the destruction of two opposite classes in Marx's vision of a communist society, everyone is able to obtain free and comprehensive development; human rights are obtained by all mankind consciously, thus the law maintaining a particular class' human rights will accordingly disappear. 
From the above two aspects of analysis, we believe that the "humanistic spirit" is the reasonable intention of Marx law philosophy. Based on this, Marx pays attention to human status, value and development and constructs the contemporary legal philosophy theoretical system with the development of real persons as fundamental purpose. He puts humanistic spirit in the development of law, saves law from bondage of god and material and from the shackles of kingship, makes law originating from people returns to people, takes real persons as the main body of law and endows law with personalities from various levels. All of these are basic tasks of the contemporary legal philosophy, and characteristics of modernity in Marx's legal philosophy.

\section{4 the Present Situation of Law-Construction in China}

Since the end of last century, China's traditional legal culture has been a fundamental transformation, at least in the institutional level, it took place by the concept of the market economy, economic globalization and the pursuit of power in an extreme way by people and so on. The main performance of the fundamental transformation is: From the "heavylight people" to" equal emphasis on Civil and criminal law " ;from procedural instrumental-ism to procedural justice; from publicizing the legal attribute to privatizing the legal attribute; from "Self-closed" to "Open Degree of legal system "; from fusions of justice and politics to judicial independence. Although there are so many changes, law-construction in China at present still have a lot of problems from the point of view of humanism value of law-construction.

For example, the capitalization of the law was quite serious, easily leading to corruption, such as using authority in exchange for money, etc. Law deteriorated from sacred impartial judgment into the slave of money. At the same time, due to high concentration of power, law gradually alienated to a violent tool to maintain national rule, rather than a selfless referee, especially some shortcomings in the government staff violating law and disciplines, official standard thought and ignore of law weaken people's supports more seriously. All sorts of alienation have become obstacles to modern development of legal philosophy.As for the reasons, the author sums up the two points:

\subsection{Chinese Legal System is Power-Omnipotent}

In the long history of China, there has never been the political pluralism as in the western society and such lack drives the formation of power-omnipotent society. Such a society formation is good at the implementation of policies but makes building legal society difficult. Modern rule of law is a deep-structured rule as it is a public participation rule. One of its core values is to try hard to draw all the citizens to participate in the process of law-making. Such participation is not only a right representation of member of society becoming a citizen but not a subject, but also the prerequisites of it. The process of legalization of the society includes the process of citizen participating, stabling their belief and devoting their loyalty. However, in the contemporary Chinese society, members are taken as outsiders and onlookers of the rule of law. Law has taken as a symbol and a sign which is quite far away from people's ordinary life and lives only in the self-discussed theory formation and participation of jurisprudents. The rule of law needs the participation of all society members. A legal citizen of a real federal society plays the role both as the strict obedient of the existing laws and the free critics of it; the defender of the realistic society and the promoter of the ideal society; the believer of the value of monocracy and the person who fulfill its meaning. On the contrary, the rule of law which led by the government takes the representation of outside rules dominated by power which control the society. This pattern, on the one hand, reinforces power-depending habit of society members; on the other hand, provides the possibility that making power as a tool for Power group achieving particular purposes on behalf of the interest of community. At the same time, rules and methods using to solve conflicts and contradictions which formed by the society itself, the colorful lives of the society members and the individual differences among them are omitted.

\subsection{Law instrumentalism in the tradition}

On the relationship between the state and the law, law instrumentalism holds that country is the purpose, and the law is a tool to safeguard the operation of the state machine. As the historical form of countries can be divided into authoritarian and democratic, the function of legal system is also divided as authoritarian instrumentalism and democratic instrumentalism. Legal instrumentalism, just as national instrumentalism, 
marks the rule of law a deep political influence, and leaves people a feeling that laws are quiet away from their social life. It looks like only special professions (as the public securities) have relationship with the law and people will not get related with it if they do not make crime. State instrumentalism weakens people's passion and devotion to the law and finally results in a deep disappointment of people in the value of law.

On the relationship between the ruling party and the rule of law, law instrumentalism still holds that law is the tool making policies standardized and stabilized. Applying the law is to apply the policies, and polices are the guidance of law making and applying. Even a lot of legal scholars have challenged such a theory since these years, as the relationship between policies and the law involves the relationship between the ruling party and the state, most scholars are not willing to discuss the relationship between the law and polices thoroughly. In recent years, some documents and rules of the party have emphasized that the party should work follow the constitution and the laws. But such regulation has not been perfectly realized. Current situation and deep historical tradition together deepen the impression that political policies are important than the law and the law is the tool to realize policies. Because of this, our society forms a policy-law binary society structure and the administrative organs pay more attention to the policy rather than the law. Such a tradition has become a persistent ailment for the process of the rule of law in our country.

On the relationship between the rule of law and economy development, many people, understanding Marxism unilaterally, take "economic base determines the law and the law reacts the economic base" as a doctrine. However, principle between economic base and superstructure is a principle in the ultimate sense, and for the specific relation and history process between them, Marx always held the idea that they should be analyzed specifically. If we understood the relationship just in a simple way, what we get would be a myth that economic development will change the rule of law instantly. However, in the process of reforming and opening and establishing market economy, if we pay all attention on the economic interest and omit the law value and target as equity, justice, freedom and human rights, we are encouraging the trend of money worship. As a result, justice competition will weaken, collusion between power and money will spread, political corruption will worsen and law and rules will be overhead. Obviously, absolutizing the theory that the law is the tool of economy development is a one-sided understanding of the relationship between the law and economy in Marxism, and the practice will bring the money-worship which means that all else targets and values can be drop because of it.

In summary, the modern Chinese legal system based on duty and state is difficult to foster the spirit of modern rule of law. Citizens undoubtedly should fulfill their legal obligations, but to fulfill these obligations is to enjoy their rights. The rights and obligations being equivalent and making a perfect combination is the best choice theoretically. However, before most people come to the consciousness that they are the real master of laws, it must take rights as the driving force to drive people fulfill their obligations. In the current stage, people's consciousness, initiative and positivity to fulfill obligations come mainly from the interests and rights but not the force power of laws and improvement of their consciousness. National standard means that the state goes first and heavier than everything else. Such an idea can easily lead to doctrine. To remove the shadow of doctrine, nationalism and nationalistic content should be removed from the legal system. If obligation standard and national standard are not removed, they should be resulted in the continuation of those traditional concepts of valuing rule of man more than rule of law, valuing moral more than interest, valuing official more than citizen, valuing penalty more than human rights and avoiding litigation.

\section{Conclusions: Contemporary Enlightenment of Marx’s Philosophy of Law}

The theory view of Marx Humanism Legal View is achieving personal existence. Its center is protecting and achieving personal freedom. All of these are closely connected with the elemental spirit of Marx Laws 
thought and the essential characteristic of socialism. The idea of Marx Humanism Legal View, one side is ethics, the other side is jurisprudence. One side is philosophy, the other side is law. On the one hand, it reflects human nature and law about metaphysics, on the other hand, it shows the balance of policy and the precision of law. It has the double meaning of theory and practice. From the view of point, Marx Humanism Legal View not only goes over the western traditional metaphysics characteristic of humanism, but also becomes a mental weapon to criticize formal rule law which is created by modern western legal rationalism on the social existence theory. At the same time, Marx Humanism Legal View has a great meaning about realizing the essence of western post-modern law, correcting Chinese traditional "the people" thought and the idea of power first.

To implement the rule of law in our country, we have to adhere to Marx's law philosophy, and carry out the modern essence of Marx's law philosophy, always put starting point and foothold of ruling of law on caring about human. To carry out humanistic spirit of Marx's philosophy of law, it is necessary to set up a philosophy of law believed by common people in modern society; the enforcement of law must fully represent and safeguard the legitimate interests of the masses, reflecting people's desire for freedom and the pursuit of progress, creating a suitable environment of law for people's survival and development and finally building a harmonious society full of humanistic care.

How to insist "Humanism" in the meaning of law concretely? In writer's opinion, first, we must be against with the positivism attitude which value and fact are separated. On legislation, we shouldn't give up the morality position in law. In judicature, we should insist criticizing the power of "bad law", and be against with "Theory of rule of law". Second, we must object to those who use power to cover the law, who use power to bully law and who use law to tease people. We should furthest reflect popular of folk character in legislation, show the humanity when enforcing and show the justice and positivism justice in procedure in judicature. And we should insist that law is above all and the power should check and balance, object to the difference in law. Last, we must insist that human's power is above all, uphold personal power is equal. All above is to show we can base on the humanity of existence power and perfect the public law's public welfare when structuring judicial system.

\section{Acknowledgement}

This paper is supported by the project of Research on the teaching methods of law and reformation of quality education in Universities of technology (2014107). Thanks are due to my tutor, Professor Li Mu for valuable suggestions.

\section{References}

[1]Marx Karl, Selections of K. Marx and F. Engels, Vol. 2. Beijing: People's Publishing House, 1995, pp.32.

[2]Marx Karl, Selections of K. Marx and F. Engels, Vol. 1. Beijing: People's Publishing House, 1995, pp.84.

[3]Marx Karl, Selections of K. Marx and F. Engels, Vol. 1. Beijing: People's Publishing House, 1995, pp.289.

[4]Marx Karl, Karl Marx and Frederick Engels, Vol. 25. Beijing: People's Publishing House, 1995, pp.892. 